\title{
GENETIC STRUCTURE OF THE LIMECOLA BALTHICA POPULATION IN THE GULF OF RIGA, BALTIC SEA
}

\author{
Oksana Fokina ${ }^{1}$, Dace Grauda ${ }^{1}$, Ingrīda Purina ${ }^{2}$, leva Bārda ${ }^{2}$, and Isaak Rashal ${ }^{1}$ \\ ${ }^{1}$ Institute of Biology, University of Latvia, 1 Jelgavas Str., Rīga, LV-1004, LATVIA \\ ${ }^{2}$ Latvian Institute of Aquatic Ecology, 4 Voleru Str., Rīga, LV-1007, LATVIA \\ \# Corresponding author, izaks.rasals@lu.Iv
}

Contributed by Isaak Rashal

\begin{abstract}
Samples of Limecola balthica with normal and deformed shells were collected from ten sites throughout the Gulf of Riga. Genetic diversity was evaluated by the retrotransposon-based iPBS method. Samples had close mutual genetic distances, which showed that all of them belong to one wider population of the Gulf of Riga. No direct relationship between the activity of retrotransposons and deformation of shells was found.
\end{abstract}

Key words: retrotransposon-based markers, iPBS, Baltic macoma, genetic distances.

\section{INTRODUCTION}

Baltic Sea is the world's largest brackish sea and has restricted water exchange with the North Sea. An increased level of eutrophication and pollution from hazardous substances has caused the Baltic Sea to be classified as one of the most polluted areas of the world (Smolarz and Bradtke, 2011). These multiple anthropogenic as well as climatic factors can lead to irreversible consequences, such as a change in the biodiversity of the Baltic (Ojaveer et al., 2010). The preservation of genetic diversity and improvement of methods for its study is one of the most important tasks nowadays.

The benthic clam Limecola balthica is widely distributed over the northern hemisphere, including in the Baltic Sea (Bondsorff and Wenne 1989; Rumohr et al., 1996). As deposit-feeders they are exposed to natural and anthropogenic origin contaminants, and therefore have been used as indicator species to monitor effects of pollution in brackish environments (Griscom et al., 2002; Lehtonen et al., 2003; 2006; Baršiene et al., 2008; Barda et al., 2014). The $L$. balthica shell is usually round or oval with triangular tops, but some of them have visible morphological deformations. Parameters like length, height, width, proportions of posterior side and flexure on it, are often used for the analysis of changes in the environment and their impact on marine ecosystem (Sokolowski et al., 2008; Genelt-Yanovskiy et al., 2017). The reasons for the various changes can be a combi- nation of several factors. According to Sokolowski et al. (2004), the number of deformed shells of L. balthica from the Gulf of Gdansk increases with the depth. The concentration of accumulated trace metals (e.g., $\mathrm{As}, \mathrm{Ag}, \mathrm{Cu}$, and $\mathrm{Zn}$ ) in the tissues might also cause deformations. The proportion of modified shells can reach up to $65 \%$ of the total population size. Over the past decade, various studies have investigated the possible effects of temperature change and predators (Genelt-Yanovskiy et al., 2017), food availability (Beukema et al., 2014), anoxia and hydrogen sulfide concentration at different depths (Sokolowski et al., 2008), acidification (Jansson et al., 2013; Van Colen et al., 2018) and trace metal and other contaminant concentrations (Sokolowski et al., 2004) on the shell growth. There exist several hypotheses to explain the causes of these changes, but the reason for these modifications is still unclear.

Impact of genetic factors on abnormalities of shell shape also is not clear. The mitochondrial DNA cytochrome oxidase I gene showed no significant differences between individuals with different shell types (Sokolowski et al., 2008). It is possible that the influence of the changing environment and the activity of retrotransposons are one of the reasons of shell shape modifications.

Inter-PBS (iPBS) is a retrotransposon-based marker method, which was suggested by Kalendar and colleagues (2010). The method is based on the possibility of retrotransposons moving around the genome, leaving their copies in 
different places, which may affect genetic diversity of a species and also phenotypes. This technique was shown to have high potential to be effective for genetic analysis in both plant and animal species, without prior knowledge of its genome. It is also suggested that in stress conditions moving of transposons is activated, which can result in increased genetic diversity revealed by iPBS markers.

In this study we used iPBS genetic markers to test for genetic differences between $L$. balthica individuals collected in geographically distant sites of the Gulf of Riga. As well we look for a possible relationship between shell shapes and genetic diversity estimated by the iPBS technique.

\section{MATERIAL AND METHODS}

Mussels were collected in the Gulf of Riga during 2012-2014 at ten study sites (Fig. 1). Specimens of $L$. balthica were collected using a Van Veen grab from the r/v "Aranda". All collected samples were immediately frozen and subsequently stored at $-20{ }^{\circ} \mathrm{C}$.

DNA was extracted from L. balthica foot tissues by an AnalytikJena kit. The quality of extracted samples was checked on $1.5 \%$ agarose gel for 2 hours at $60 \mathrm{~V}$. A spectrophotometer was used for more accurate analysis of type and concentration of contaminants in each sample.

Obtained DNA was found to be unstable, apparently the mollusk's extracted DNA sample contain enzymes causing DNA fragmentation. Using the iPBS method requires good quality unfragmented DNA. Therefore, it is recommended that $L$. balthica DNA samples be analysed not later than a day after DNA extraction.

Seventeen iPBS primers (Table 1), previously having shown a high level of effectiveness both in animals and plants (Kalendar et al., 2010), were used for preliminary

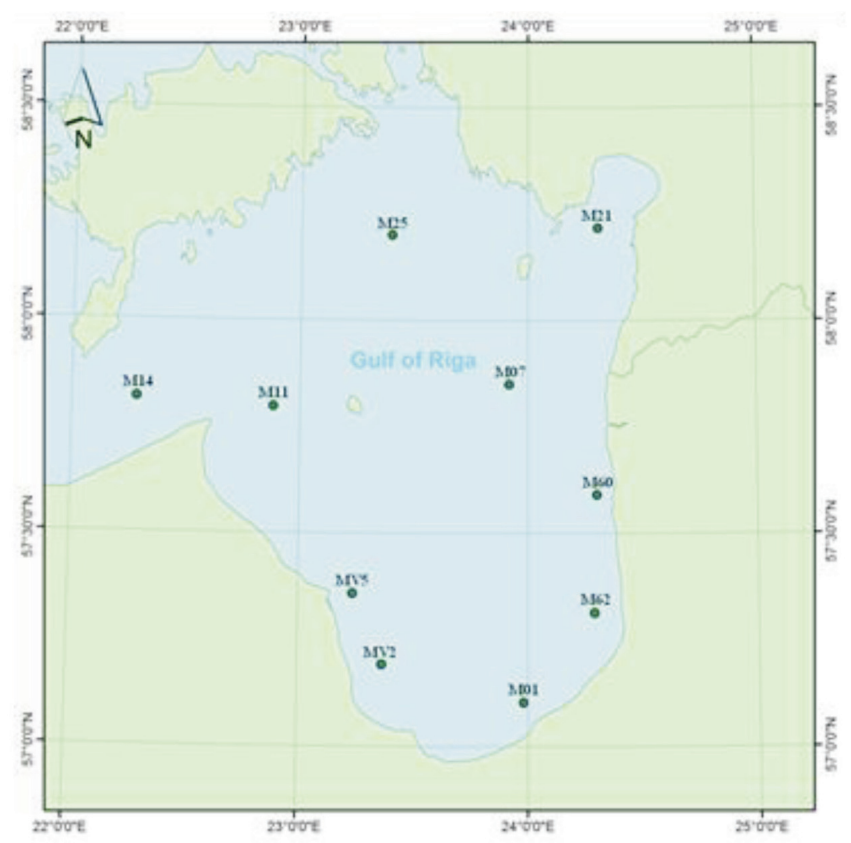

Fig. 1. Limecola balthica collection spots in the Baltic Sea.
Table 1. The list of iPBS-specific primers used in preliminary screening

\begin{tabular}{ll}
\hline Primer & Sequence \\
\hline 2076 & GCTCCGATGCCA \\
2079 & AGGTGGGCGCCA \\
2080 & CAGACGGCGCCA \\
2081 & GCAACGGCGCCA \\
$2232 *$ & AGAGAGGCTCGGATACCA \\
2237 & CCCCTACCTGGCGTGCCA \\
2238 & ACCTAGCTCATGATGCCA \\
2239 & ACCTAGGCTCGGATGCCA \\
2271 & GGCTCGGATGCCA \\
2272 & GGCTCAGATGCCA \\
2273 & GCTCATCATGCCA \\
2375 & TCGCATCAACCA \\
2377 & ACGAAGGGACCA \\
2378 & GGTCCTCATCCA \\
2390 & GCAACAACCCCA \\
$2394 *$ & GAGCCTAGGCCA \\
2415 & CATCGTAGGTGGGCGCCA \\
\hline
\end{tabular}

*primers which were selected for the further analysis

screening to find the most suitable primers with a large number of polymorphic loci. The PCR procedure was as follows. The PCR programme consisted of 32 cycles: first denaturation cycle at $95{ }^{\circ} \mathrm{C}$ for 3 minutes, 30 repeated cycles $\left(95{ }^{\circ} \mathrm{C}\right.$ for $30 \mathrm{~s}, 50{ }^{\circ} \mathrm{C}$ for $40 \mathrm{~s}, 68{ }^{\circ} \mathrm{C}$ for $1 \mathrm{~min}$ ), and the last elongated cycle at $72{ }^{\circ} \mathrm{C}$ for 5 minutes. The final concentration of reagents in the $25 \mu \mathrm{l}$ PCR mixture was: 1xDreamTaq Buffer, $200 \mu \mathrm{M}$ dNTPs, 2.5 U DreamTaq polymerase, $0.06 \mathrm{U}$ Pfu DNA polymerase and $1 \mu \mathrm{M}$ primer. The PCR products were electrophoresed on $1.7 \%$ agarose gel for 3.5 hours at $70 \mathrm{~V}$, and then gel was stained with ethidium bromide.

Experimental data were processed with Popgene software to identify differences among polymorphic loci within and among individuals from different sampling places. Nei's genetic parameters and principal coordinates analysis were calculated using NTSYSpc 2.1 software.

\section{RESULTS}

Two of seventeen preliminary tested iPBS-specific primers with the highest numbers of polymorphic loci (2232 and 2394) were chosen for subsequent analysis. Altogether those primers revealed 40 polymorphic loci: 17 loci with primer 2232 and 23 loci with primer 2394, respectively. Percentage of polymorphic loci in each site varied from $53 \%$ in site M21 to $85 \%$ in M14. From 84 sampled individuals, 39 clams were with some deformation and 45 had normal shells (Table 2).

The most similar samples according Nei`s distance were those collected from sampling sites M60 and M62 (genetic distance 0 ). These places are located at a short geographical distance. However, in other cases, the level of genetic distance between nearby locations, for example, between sites 
Table 2. The number of collected samples and genetic characteristics per sampling site

\begin{tabular}{|c|c|c|c|c|c|c|c|c|c|c|c|}
\hline & M01 & M07 & M11 & M14 & M21 & M25 & M60 & M62 & MV2 & MV5 & In total \\
\hline Normal shell & 3 & 4 & 5 & 4 & 6 & 6 & 5 & 4 & 4 & 4 & 45 \\
\hline Deformed shell & 5 & 2 & 5 & 5 & 0 & 5 & 7 & 2 & 3 & 5 & 39 \\
\hline Number of polymorphic loci & 27 & 27 & 24 & 34 & 21 & 27 & 26 & 28 & 26 & 32 & 40 \\
\hline Percentage of polymorphic loci & 68 & 68 & 60 & 85 & 53 & 68 & 65 & 70 & 65 & 80 & 100 \\
\hline
\end{tabular}

Table 3. Nei`s unbiased measures of genetic diversity

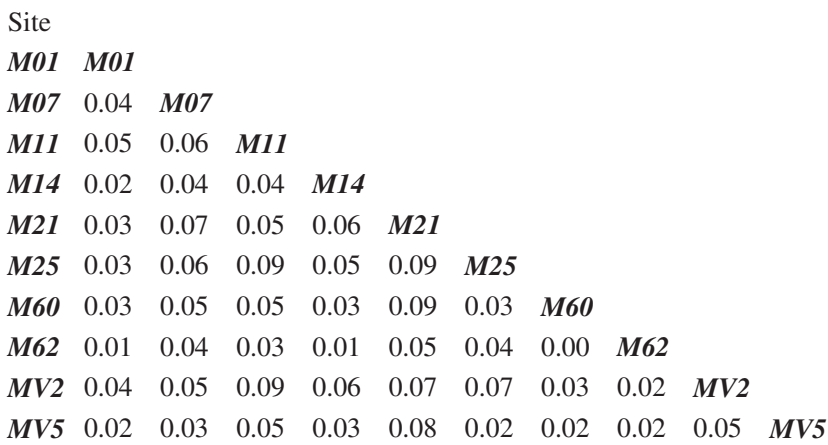

MV2 and MV5, was higher than distances between M01 and M14, which were located on opposite sides of the Gulf of Riga (Table 3). Despite the high number of polymorphic loci in each population, the level of Nei's genetic distance among all sites varied only from 0 to 0.09 (Table 3).

Principal coordinates analysis (Fig. 2) showed some genetically separated sites. Site M21 was geographically distant from other sites and also had the highest level of genetic distance from other sites: from 0.05-0.09 (Table 3). Samples of some other sites (M11 and M07) were grouped separately (Fig. 2). Site M11 was closest to the open Baltic Sea, while M07 was in the central part of the gulf. Nevertheless, a general positive correlation between geographical and genetic distance was not observed.
No positive correlation was observed between genetic variability of the used molecular markers and shell shapes. The percentage of polymorphic loci in both groups was similar: $92.5 \%$ in deformed shells and $97.5 \%$ in samples with a typical shell form (data not shown).

\section{DISCUSSION}

According to monitoring data for L. balthica in the White Sea (Genelt-Yanovskiy et al., 2017) for the last 20 years, predators have a smaller influence on mollusks than temperature change. A huge number of studies devoted to bivalve mollusks and their adaptation to a changing environment have revealed serious morphological, histological and cytogenetic changes of these creatures (Sokolowski et al., 2004). Despite many positive correlations with depth of the clams and the concentration of heavy metals in tissue, the cause of deformation of the shells has not yet been found as well as the causes of the so often occurring tumors in gill cells of the deformed-shell bivalves (Sokolowski et al., 2004).

All 40 loci revealed by two applied primers were polymorphic. In spite of a large number of alleles, the genetic distance between populations was low and therefore no strong clustering of sampling sites was observed. This showed that samples from the sites probably belong to one wider population of the Gulf of Riga.

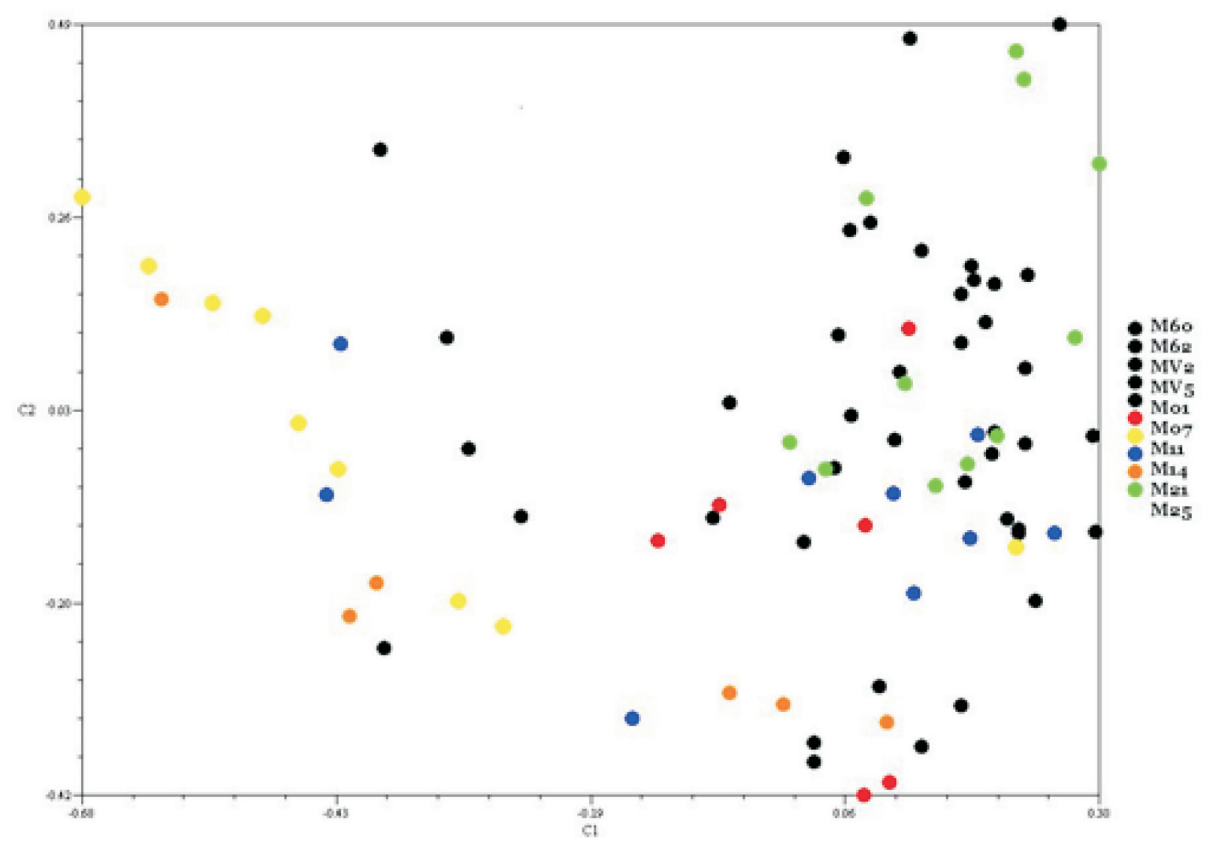

Fig. 2. Principal coordinates analysis based on differences of polymorphic loci within and among 10 sites. The sites are displayed in different colours, each sample is visualised as a separate point (NTSYSpc 2.1 software). 
A direct relationship between the activity of retrotransposons and deformation of shells in our investigation was not found. It should be noted that the shell deformation has different morphological features, perhaps the reasons for their appearance were some environmental, not genetic causes. Similar data of homogeneous structure were obtained by Sokolowski et al., (2008) using mitochondrial DNA cytochrome oxidase I region of bivalves in the Gulf of Gdansk.

Data on the genetic diversity of bivalves in Gulf of Riga using retrotransposons are published for the first time; this information may help in the conservation and study of biodiversity in the Baltic Sea. For further analyses of the genetic diversity of the species, it would be worthwhile to increase the amount of collected material and widen the number and types of applied molecular markers, including those, which were already successful used in bivalves in some other geographic areas (see, for example, Becquet et al, 2009, Lasota et al, 2018, Šatović et al., 2019).

\section{REFERENCES}

Barda, I., Purina, I., Rimsa, E., Balode, M. (2014). Seasonal dynamics of biomarkers in infaunal clam Macoma balthica from the Gulf of Riga (Baltic Sea). J. Marine Syst., 129, 150-156.

Baršienè, J., Andreikènaitė, L., Garnaga, G., Rybakovas, A. (2008). Genotoxic and cytotoxic effects in the bivalve mollusks Macoma balthica and Mytilus edulis from the Baltic Sea. Ekologija, 54 (1), 44-50.

Becquet, V., Lanneluc, I., B. Simon-Bouhet, B., Garcia, P. (2009). Microsatellite markers for the Baltic clam, Macoma balthica (Linné, 1758), a key species concerned by changing southern limit, in exploited littoral ecosystems. Conserv. Gen. Res., 1, 265-267.

Beukema, J., Cadée, G. C., Dekker, R., Philippart, C. J. M. (2014). Annual and spatial variability in gains of body weight in Macoma balthica (L.): Relationships with food supply and water temperature. J. Exper. Marine Biol. Ecol., 457, 105-112.

Bondsorff, E., Wenne, R. (1989). A comparison of condition indices of Macoma balthica (L.) from the northern and southern Baltic Sea. Netherlands J. Sea Res., 23 (1), 45-55.

Genelt-Yanovskiy, E. A., Aristov, D. A., Poloskin, A. V., Nazarova, S. A. (2017). Trends and drivers of Macoma balthica L. dynamics in Kandalaksha Bay, the White Sea. J. Marine Biol. Assoc. United Kingdom, 98 (spec. issue 1), 1-12.
Griscom, S. B., Fisher, N. S, Luoma, S. N. (2002). Kinetic modelling of Ag, $\mathrm{Cd}$ and Co bioaccumulation in the clam Macoma balthica: quantifying dietary and dissolved sources. Marine Ecol. Progr. Ser., 240, 127-141.

Jansson, A., Norkko, J., Norkko, A. (2013). Effects of reduced pH on Macoma balthica larvae from a system with naturally fluctuating pH-dynamics. PLoS ONE, 8 (6), e68198.

Kalendar, R., Antonius, K., Smykal, P., Schulman A. H. (2010). iPBS: A universal method for DNA fingerprinting and retrotransposon isolation. Theor. Appl. Gen., 121, 1419-1430.

Lasota, R., Sokolowski, A., Smolarz, K., Sromek, L., Dublinowska, M. (2018). Multimarker response to salinity stress in two estuarine bivalves of different genetic diversity: Mya arenaria and Limecola balthica from the Gulf of Gdańsk (southern Baltic Sea). Invertebrate Biol., 137 (3), 250-263.

Lehtonen, K. K. Leiniö, S. (2003). Effects of exposure to copper and malathion on metallothione in levels and acetylcholinesterase activity of the mussel Mytilus edulis and the clam Macoma balthica from the Northern Baltic Sea. Bull. Environ. Contamin. Toxicol., 71, 489-496.

Lehtonen, K. K., Leiniö, S., Schneider, R., Leivuori, M. (2006). Biomarkers of pollution effects in the bivalves Mytilus edulis and Macomabalthica collected from the southern coast of Finland (Baltic Sea). Marine Ecol. Progr. Series, 322, 155-168.

Nei, M. (1978). Estimation of average heterozygosities and genetic distance from a small number of individuals. Genetics, 89, 583-590.

Ojaveer, H., Jaanus, A., MacKenzie, B. R., Martin, G., Olenin, S., Radziejewska, T., Telesh, I., Zettler, M. A., Zaiko A. (2010). Status of biodiversity in the Baltic Sea. PLOS ONE, 5 (9), e12467.

Rumohr, H., Bonsdorff, E., Pearson, T. H. (1996). Zoobenthic succession in Baltic sedimentary habitats. Arch. Fishery Marine Res., 44, 179-214.

Smolarz, K., Bradtke, K. (2011). Bioindicative potential of shell abnormalities occurring in the clam Macoma balthica (L.) from the Baltic Sea. Marine Pollut. Bull., 62, 1421-1426.

Sokolowski, A., Pawlikowski, K., Wolowicz, M., Garcia, P., Namiesnik, J. (2008). Shell deformations in the Baltic Clam Macoma balthica from Southern Baltic Sea (the Gulf of Gdansk): Hypotheses on environmental effects. Ambio, 37 (2), 93-100.

Sokolowski, A., Wolowicz, M., Hummel, H., Smolarz-Gorska, K., Fichet, D., Radenac, G., Thiriot-Quievreux, C., Namiesnik, J. (2004). Abnormal features of Macoma balthica (Bivalvia) in the Baltic Sea: Alerting symptoms of environmental adversity? Marine Pollut. Bull., 49 (1-2), 17-22.

Šatović, E., Luchetti, A., Pasantes, J. J., García-Souto, D., Cedilak, A., Mantovani B., Plohl, M. (2019). Terminal-repeat retrotransposons in miniature (TRIMs) in bivalves. Sci. Rep., 9, 19962.

Van Colen, C., Jansson, A., Saunierd, A., Lacoue-Labathed, T., Vincxa, M. (2018). Biogeographic vulnerability to ocean acidification and warming in a marine bivalve. Marine Pollut. Bull., 126, 308-311.

\section{BALTIJAS JŪRAS RĪGAS LİČA LIMECOLA BALTHICA POPULĀCIJAS GEENĒTISKĀ STRUKTŪRA}

Limecola balthica paraugi tika ievākti desmit dažādos attālinātos Baltijas jūras Rīgas līča punktos. Starp ievāktajiem indivīdiem bija eksemplāri gan ar tipiskiem, gan arī ar deformētiem gliemežvākiem. DNS molekulārie markiieri tika noteikti ar iPBS metodi, kas pamatojās uz retrotranspozonu mainības analīzi. Noteikts, ka paraugi no dažādām ievākšanas vietām ir génētiski tuvi, kas visdrīzāk liecina, ka $L$. balthica Rīgas līcī veido vienu kopīgu populāciju. Saistība starp retrotranspozonu aktivitāti un deformēto gliemežvāku parādīšanos šajā pētījumā nav konstatēta. 